\title{
\begin{tabular}{lllllllllllll}
$\mathrm{A}$ & $\mathrm{R}$ & $\mathrm{T}$ & $\mathrm{I}$ & $\mathrm{C}$ & $\mathrm{U}$ & $\mathrm{L}$ & $\mathrm{O}$ \\
\hline
\end{tabular} \\ Sintering of new SiC-Phosphate composite materials for grinding wheels fabrication
}

\author{
R.F.SILVA' ${ }^{1}$, H.H.BERLINOV ${ }^{2}$ \\ 'University of Aveiro, Department of Engineering Glass and Ceramic, CICECO, Aveiro, Portugal. \\ ${ }^{2}$ University of Chemical Technology and Metallurgy-Sofia, Department of Silicate Technology, Sofia, Bulgaria.
}

\begin{abstract}
The effect of several variables such as molar ratio $\mathrm{P}_{2} \mathrm{O}_{5} / \mathrm{B}_{2} \mathrm{O}_{3}(\mathrm{X})$, temperature and heating cycle on the strength of chemically bonded SiC materials for grinding wheels fabrication was studied. It was shown that the highest compressive strength (52.4 MPa) could be obtained using an optimal molar ratio $\mathrm{X}=4.5$ and a multiple step heating cycle up to a sintering temperature of $800^{\circ} \mathrm{C}$. DTA, XRD, SEM and dilatometrical analysis were performed to follow the different stages of the structural development.
\end{abstract}

Keywords: phosphate bonding, strength, grinding tools, SiC, chemical bonding.

\section{Sinterizacion de nuevos materiales compuestos de sic aglomerados con fosfatos para la fabricacion de muelas abrasivas}

Se estudia el efecto de diferentes variables tales como la razón molar $\mathrm{P}_{2} \mathrm{O}_{5} / \mathrm{B}_{2} \mathrm{O}_{3}(\mathrm{X})$, temperatura y ciclo de calentamieno sobre la resistencia de materiales de $\mathrm{SiC}$ aglomerados quimicamente para la fabricación de muelas arasivas. Se ha comprobado que la más alta resistencia a la compresión (52,4MPa) pueda obtenerse usando una razón molar òptima $\mathrm{x}=4,5 \mathrm{y}$ un ciclo de calentamiento en múltiples etapas hasta la temperatura de $800^{\circ} \mathrm{C}$. Estudios mediante ATD, DRX, MEB y análisis dilatométricos fueron llevados a cabo para seguir las diferentes etapas del desarrollo microestructura.

Palabras clave: Aglomeración química, resistencia mecánica, muelas abrasivas de SiC

\section{INTRODUCTION}

The chemistry of different kind of materials bonded by phosphate binders was reviewed and classified by Kingery (1) and Cassidy (2). The good adhesive properties, the high refractoriness and thermal resistance, the superior mechanical resistance and the ability of phosphate binders to hardening by polycondensation, gives an opportunity for their industrial application as special kinds of glues, refractories, cements, ceramics and metal coatings production (3).

Usually, these binding materials are phosphate solutions, namely hydrophosphates, yielded by dissolving oxides or hydroxides in water and neutralization with phosphoric acid. Such binders are saturated molecular solutions. Through the hardening process the binder turns to a disperse system due to the hard phase separation.

The physical and the mechanical properties of aluminum phosphate binders are improved by $\mathrm{B}_{2} \mathrm{O}_{3}$ modification, leading to formation of condensed aluminum phosphates, at lower temperatures than in the case of pure aluminum phosphate binders, or to $\mathrm{BPO}_{4}$ formation $(4,5)$. For example, the strength of porcelain is known to considerably increase by addition of $\mathrm{BPO}_{4}(6)$.

The insertion of inert additives allows varying the mechanical, chemical, thermal and electrical properties in a wide range. Various kinds of materials based on aluminum phosphate binders with SiC additions were developed for refractory production $(7,8)$. In spite of this, the use of phosphate binders in abrasive grinding tools hasn't been researched yet. Hence, we are focusing our work on the replacing of conventional binders by boron phosphate matrices in such articles, which most important characteristics are: i) Self-sharpening - the ability of the grinding tool to loose by bonding strength lack, the abrasive grains that reached a critical radius of roundness of their cutting edge, and to replace them by new sharp grains at the surface; ii) Structure - the abrasive material, binder and pores amount and volume; iii) Hardness - the capacity of the binder to hold the abrasive grains (9).

\section{EXPERIMENTAL PROCEDURE}

\subsection{Starting materials}

The starting materials were $\alpha$-SiC (ZZAM -Ukraine; main fraction $200-250 \mu \mathrm{k}$ ), $\mathrm{H}_{3} \mathrm{PO}_{4}$ (Merck; 85\%), $\mathrm{B}_{2} \mathrm{O}_{3}$ (Merck), kaolin.

\subsection{Specimen preparation}

The binders were prepared from $65 \%$ water solution of $\mathrm{H}_{3} \mathrm{PO}_{4}$ by step-by-step small additions of $\mathrm{B}_{2} \mathrm{O}_{3^{\prime}}$ during heating and continuously mixing for about $20 \mathrm{~min}$. After few days, the obtained colloidal solutions decompose into crystalline and liquid phases. Solutions with molar ratio $\mathrm{P}_{2} \mathrm{O}_{5} / \mathrm{B}_{2} \mathrm{O}_{3}(\mathrm{X})=3,3.5,4$ and 4.5 were prepared. The final abrasive grades were processed by mixing $70 \mathrm{wt} . \%$ of $\mathrm{SiC} \mathrm{(60/}$ 70 mesh), 11.83wt.\% phosphate binder and 18.17wt.\% kaolin. Bars $(5 \times 5 \times 50 \mathrm{~mm})$ and cylinders $(\varnothing 20 \times 20 \mathrm{~mm})$ were produced by uniaxial pressing at $50 \mathrm{MPa}$ for mechanical characterization. The green samples were dried at $60^{\circ} \mathrm{C}$ for $24 \mathrm{~h}$. All samples were heated at $4{ }^{\circ} \mathrm{C} / \mathrm{min}$ up to $550^{\circ} \mathrm{C}$, excepting those from compositions with molar ratio $\mathrm{X}=3$ and 4.5 that were sintered at $550^{\circ} \mathrm{C}$ or $800^{\circ} \mathrm{C}$ under special heating cycles (Fig. 1) based on preliminary dilatometrical and DTA experiments (Fig. 2 and Fig. 3).

\section{Results and Discussion}

The colloidal solutions were separated into crystalline and liquid phases. X-ray Diffraction Analysis (XRD) proved that the crystals, after drying at $60^{\circ} \mathrm{C}$, were consisted of boron orthophosphate. Also, XRD indirectly demonstrated that the liquid phase is pure orthophosphoric 
acid as $\mathrm{AlPO}_{4}$ was formed through its reaction with $\mathrm{Al}_{2} \mathrm{O}_{3}$ from kaolin additions. The boron orthophosphate crystals were then separated from the solutions and heated at 120 and $1000^{\circ} \mathrm{C}$ during $4 \mathrm{~h}$, loosing $45 \%$ of its initial mass, which proves that the obtained phase contained crystalline water, accordingly with the results reported from Kmecel et al. (10).

Fig. 3 exhibits the DTA traces of specimens with $X=3$ and 4.5 under a rate of heating of $3^{\circ} \mathrm{C} / \mathrm{min}$. The large endothermic peak that appears at $900^{\circ} \mathrm{C}$ is associated with the evolution of water from $\mathrm{BPO}_{4}$ and the formation of $\mathrm{AlPO}_{4}$ as a result of the reaction between $\mathrm{H}_{3} \mathrm{PO}_{4}$ and $\mathrm{Al}_{2} \mathrm{O}_{3}$ from kaolin.

Fig. 4 exhibits the XRD spectra for the compositions with $\mathrm{X}=3$, $3.5,4$ and 4.5 heated at $4^{\circ} \mathrm{C} / \mathrm{min}$ up to $550^{\circ} \mathrm{C}$. The missing of the peaks typical for $\mathrm{AlPO}_{4}$ is due to the endothermic processes for dehydration of $\mathrm{BPO}_{4}$ and the phase transformations in kaolin, which prevent the formation of aluminum phosphate phase. The XRD spectra of samples sintered at $550^{\circ} \mathrm{C}$ and $800^{\circ} \mathrm{C}$ under the special heating cycle shown on Fig. 2, are given on Fig. 5 and Fig. 6, respectively. Obviously, in samples with molar ratio $\mathrm{X}=3$ sintered at $550^{\circ} \mathrm{C}, \mathrm{AlPO}_{4}$ formation started along with kaolin and $\mathrm{BPO}_{4}$. Also, by increasing the solutions acidity $(\mathrm{X}=$

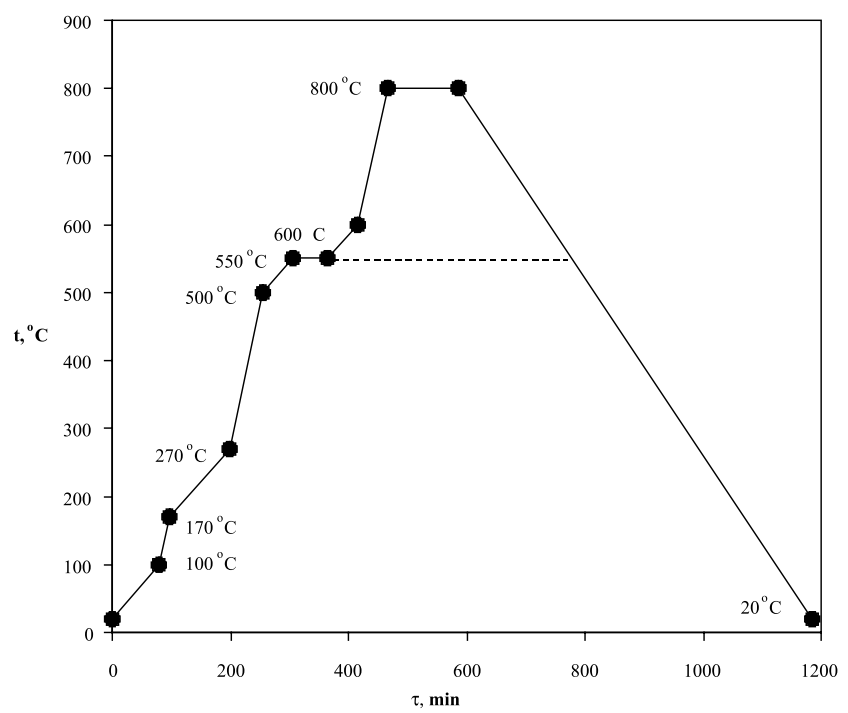

Figure 1 - Profile of the special sintering cycle with multiple step heating used for samples with $\mathrm{P}_{2} \mathrm{O}_{5} / \mathrm{B}_{2} \mathrm{O}_{3}$ molar ratio $(\mathrm{X})=3$ and 4.5.

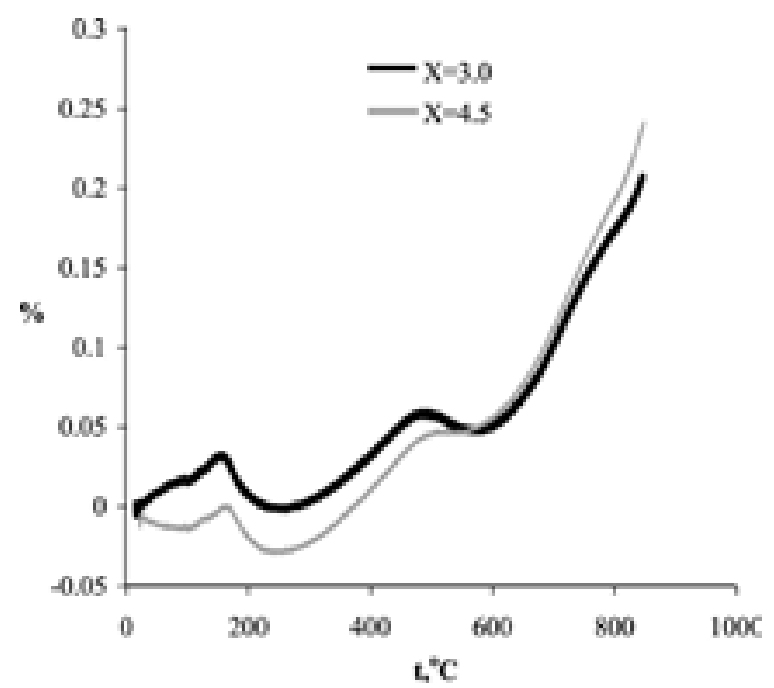

Figure 2 - Dilatometrical analysis of samples with $\mathrm{P}_{2} \mathrm{O}_{5} / \mathrm{B}_{2} \mathrm{O}_{3}$ molar ratio $(\mathrm{X})=3$ and 4.5 .

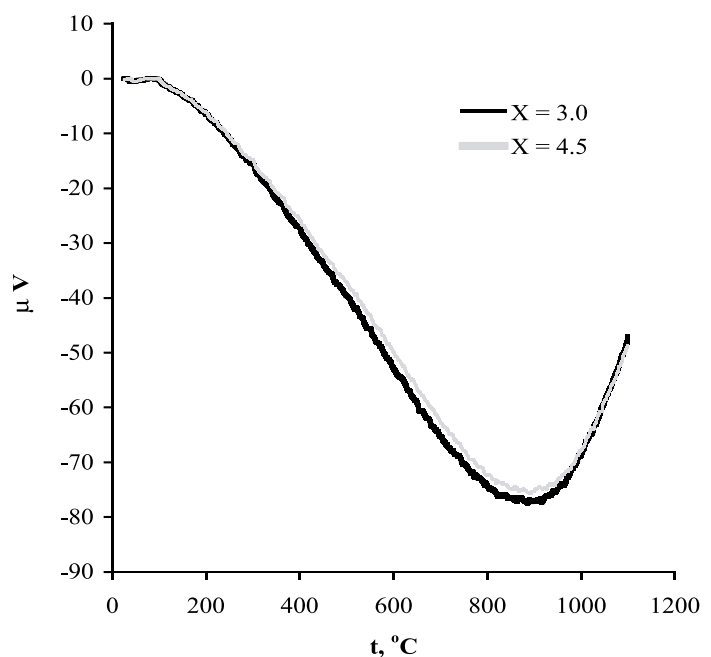

Figure 3 - DTA analysis of samples with $\mathrm{P}_{2} \mathrm{O}_{5} / \mathrm{B}_{2} \mathrm{O}_{3}$ molar ratio $(\mathrm{X})=$ 3 and 4.5 .

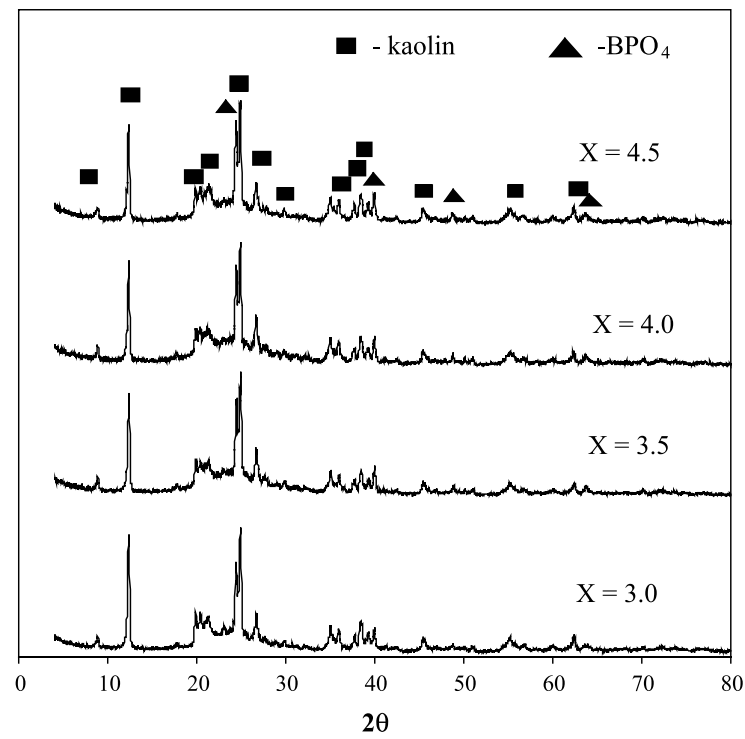

Figure 4 - XRD spectra of samples with $\mathrm{P}_{2} \mathrm{O}_{5} / \mathrm{B}_{2} \mathrm{O}_{3}$ molar ratio $(\mathrm{X})=3$, $3.5,4$ and 4.5 , heated at $4^{\circ} \mathrm{C} / \mathrm{min}$ up to $550^{\circ} \mathrm{C}$.

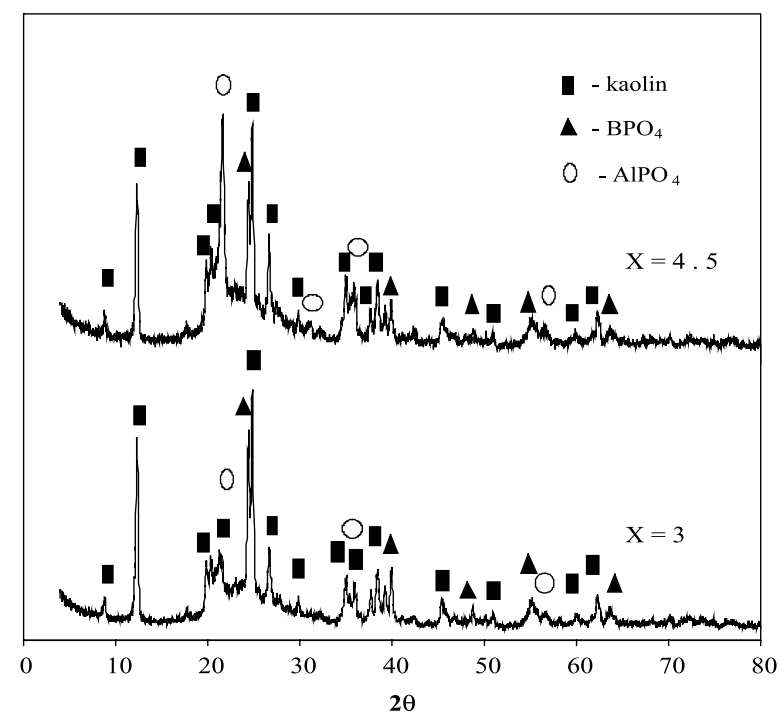

Figure $5-\mathrm{XRD}$ spectra of samples heated up to $550^{\circ} \mathrm{C}$ with multiple steps heating. 

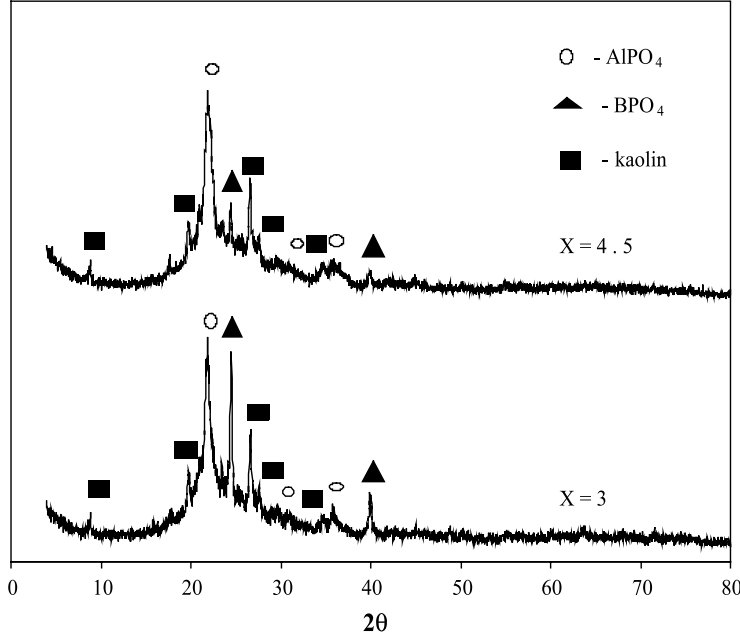

Figure 6 - XRD spectra of samples heated up to $800^{\circ} \mathrm{C}$ with multiple steps heating.

4.5), the amount of aluminum phosphate phase rises (Fig. 5). The XRD analysis of samples sintered at $800^{\circ} \mathrm{C}$ (Fig. 6) shows the presence of the same phases but the amount of $\mathrm{BPO}_{4}$ decreases to compensate the amorphous phase formation, which provides a higher strength. All the referred XRD spectra were taken for samples corresponding to the binder matrix and not the final SiC-phosphate composite because the $\mathrm{SiC}$ peak masks all the others due to the high amount of this phase.

Samples of all compositions were finally mechanical characterized by bending and compressive tests. The corresponding results are listed in Tables 1 to 3. It can be seen that, by increasing the dwell temperature and the heating duration, the mechanical strength raises, since the needed time and energy for particles/matrix consolidation, densification and amorphous phase formation is provided. Fig. 7 show typical fracture microstructures of samples with $\mathrm{X}=3$ and 4.5 sintered at constant heating rate or multiple step heating, revealing a $\mathrm{SiC}$ transgranular failure mode with no net differences between the tested grades.

TABle I. "MeChANICAL PROPERTIES OF COMPOSITIONS HEATED AT $4^{\circ} \mathrm{C} / \mathrm{min}$ UP TO $550^{\circ} \mathrm{C}$ "

\begin{tabular}{|c|c|c|}
\hline $\begin{array}{c}\text { Molar ratio, } \\
\left.\mathbf{P}_{2} \mathbf{O}_{5} / \mathbf{B}_{\mathbf{2}} \mathbf{O}_{3} \mathbf{(} \mathbf{(}\right)\end{array}$ & $\begin{array}{c}\text { Bending } \\
\text { strength, } \mathbf{M P a}\end{array}$ & $\begin{array}{c}\text { Compressive } \\
\text { strength, MPa }\end{array}$ \\
\hline 3 & 12.1 & 28.8 \\
\hline 3.5 & 12.8 & 39.1 \\
\hline 4 & 17.4 & 49.3 \\
\hline 4.5 & 11.1 & 37.3 \\
\hline
\end{tabular}

TABLE II. “MeChANICAL PROPERTIES OF SAMPLES SINTERED AT $550^{\circ} \mathrm{C}$ WITH MULTIPLE STEPS HEATING"

\begin{tabular}{|c|c|c|}
\hline $\begin{array}{c}\text { Molar ratio, } \\
\left.\mathbf{P}_{\mathbf{2}} \mathbf{O}_{\mathbf{5}} / \mathbf{B}_{\mathbf{2}} \mathbf{O}_{\mathbf{3}} \mathbf{(} \mathbf{(}\right)\end{array}$ & $\begin{array}{c}\text { Bending } \\
\text { strength, } \mathbf{M P a}\end{array}$ & $\begin{array}{c}\text { Compressive } \\
\text { strength, } \mathbf{M P a}\end{array}$ \\
\hline 3 & 11.5 & 36.7 \\
\hline 4.5 & 13.2 & 40.9 \\
\hline
\end{tabular}

TABLE III "Mechanical properties of samples sintered at $800^{\circ} \mathrm{C}$ with multiple steps heating"

\begin{tabular}{|c|c|c|}
\hline $\begin{array}{c}\text { Molar ratio, } \\
\left.\mathbf{P}_{2} \mathbf{O}_{5} / \mathbf{B}_{\mathbf{2}} \mathbf{O}_{\mathbf{3}} \mathbf{(} \mathbf{(}\right)\end{array}$ & $\begin{array}{c}\text { Bending } \\
\text { strength, } \mathbf{M P a}\end{array}$ & $\begin{array}{c}\text { Compressive } \\
\text { strength, } \mathbf{M P a}\end{array}$ \\
\hline 3 & 13.2 & 44.2 \\
\hline 4.5 & 15.7 & 52.4 \\
\hline
\end{tabular}
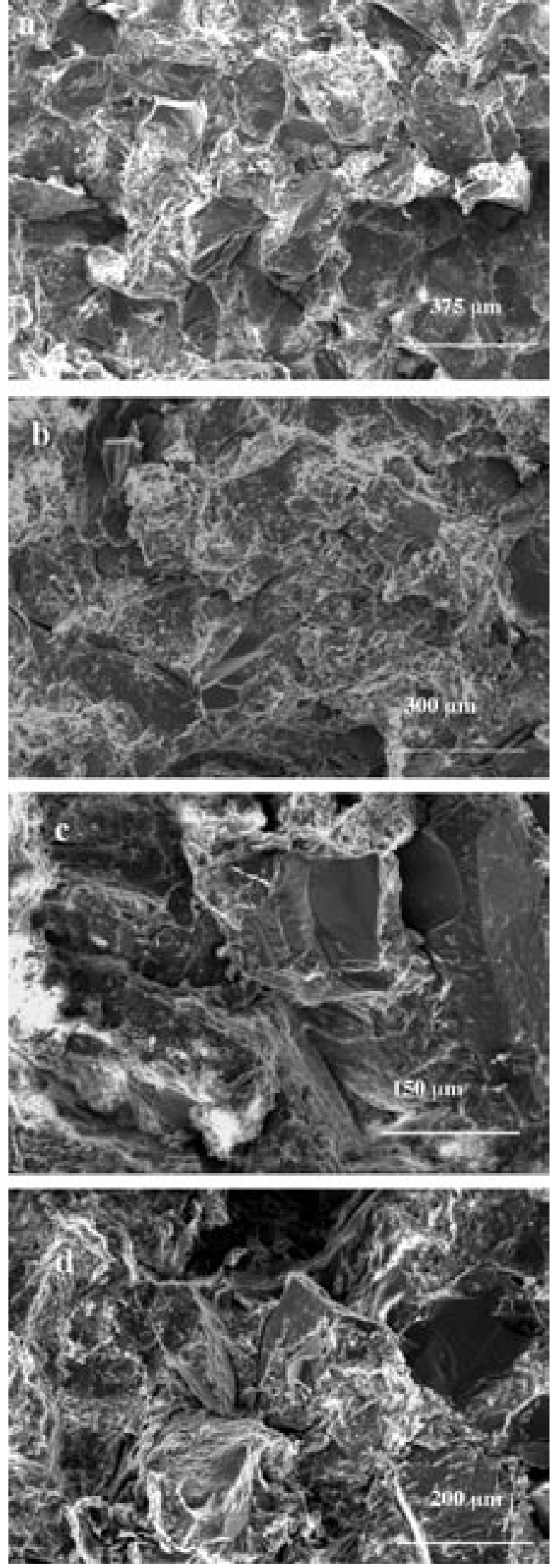

Figure 7 - Representative SEM micrographs of $(\mathrm{X}) \mathrm{P}_{2} \mathrm{O}_{5} / \mathrm{B}_{2} \mathrm{O}_{3}$ molar ratio $(X)=3$ compositions heated at $4^{\circ} \mathrm{C} / \mathrm{min}$ up to $550^{\circ} \mathrm{C} ;(\mathrm{b}) \mathrm{X}=$ 4.5 compositions heated at $4^{\circ} \mathrm{C} / \mathrm{min}$ up to $550^{\circ} \mathrm{C}$; (c) $\mathrm{X}=3$ samples sintered at $550^{\circ} \mathrm{C}$ with multiple steps heating; (d) $\mathrm{X}=4.5$ samples sintered at $800^{\circ} \mathrm{C}$ with multiple steps heating. 


\section{CONCLUSIONS}

The use of colloidal solutions of $\mathrm{B}_{2} \mathrm{O}_{3}$ into $\mathrm{H}_{3} \mathrm{PO}_{4}$ are a very promising alternative route for binder preparation for $\mathrm{SiC}$ abrasive tools, as relatively low processing temperatures are used and final thermal and mechanical properties are kept. The presence of $\mathrm{BPO}_{4}$ in the phosphate matrix compositions lowers the temperature needed for amorphous phase formation. The amount of the amorphous phase increases the final mechanical strength of the SiC-phosphate composite materials. Also, by increasing the sintering temperature and the heating step time, the mechanical strength rises as the time and energy for the composite consolidation and amorphous phase formation is guaranteed.

\section{REFERENCES}

1. W.D.Kingery, "Fundamental study of phosphate bonding refractories", J.Am.Ceram. Soc., 33, 239-250 (1950)
2. J. E. Cassidy, "Phosphate bonding then and now", Am. Ceram. Soc. Bull., 56, 640-643 (1977)

3. H.Boiadjieva, The Technology of Binding Materials, Sofia, 286-289 (2001)

4. M. M. Suichev., "Inorganic binders", Leningrad, Himia, 73-74 (1986)

5. V. F. Tikavi, "The influence of $\mathrm{B}_{2} \mathrm{O}_{3}$ to the thermal transformations of aluminium phosphate binders" Izv.Acad. Nauk SSSR, Neorg Mater., 9 [9], 1608 - 1700 (1973),

6. A. Baykal, M. Kizilyalli, M. Toprak, R. Kniep, "Hydrothermal and Microwave Synthesis of Boron Phosphate, $\mathrm{BPO}_{4}$ ", Turk J.Chem, 25, 425 - 432 (2001)

7. V. K. Marghusian and R. Naghizadeh, “Chemical Bonding of Silicon Carbide" J. Eur. Ceram. Soc., 19, 2815 - 2821 (1999)

8. Jeng-Maw Chiou, D. D. L. Chung, "Improvement of the temperature resistance of aluminium-matrix composites using an acid phosphate binder", J. Mat.Science, 28, 1447 - 1470 (1993)

9. V.N.Bakulia, "The basis of designing and production of abrasive and diamond tools", Moskow "Mashinostroenie", (1975), 81 - 84

10. Primoz Kmecl and Peter Bukovec, "Boronphosphate its synthesis, gradual crystallisation and characterisation of bulk properties", Acta Chim. Slov., 46 (2), $161-171$ (1999)

Recibido: 1.2 .03

Aceptado: 30.11 .03 